\title{
Phytocoenological researches on the grasslands of the middle and inferior basin of Crişul Negru river
}

\author{
Codrin Gavra \\ University of Oradea, Faculty of Environmental Protection, Oradea, Romania \\ gavracodrin@yahoo.com
}

SUMMARY

The meadowlands from the middle and inferior basin of Crisul Negru river form an area with rich flora and vegetation suitable for a complex phytocoenological research and an ecologic and bio-economical study of the floor vegetation.

After conducting a number of 80 phytocoenological surveys on the meadowlands near Apateu and Satu Nou villages (Arad county, Romania), respectively near Cociuba Mare and Mărțihaz villages (Bihor county, Romania) there have been identified a number of fifteen vegetal associations from which one is examined in this work.

The paper presents the hygrophilic association Typhetum latifoliae Lang 1973 on the grasslands of the middle and inferior basin of Crişul Negru river, association classified from the coenotaxonomic point of view in the alliance Phragmition communis Koch 1926, order Phragmitetalia Koch 1926, class Phragmitetea australis R. Tüxen et Preising 1942.

Keywords: ecological factors, floristic elements, life forms, phytocoenological study, vegetal association

\section{ÖSSZEFOGLALASS}

A Fekete-Körös középsö és alsó vizgyüjtöinek rétjein található gazdag növényvilág alkalmas komplex fitocönológiai kutatások elvégzésére, illetve a vegetáció ökológiai és bioökonómiai tanulmányozására.

Az Apáti és Simonyifalva (Arad megye), illetve Alsókocsoba és Marciháza (Bihar megye) közelében lévő réteken elvégzett 80 fitocönológiai tanulmányt követöen 15 növényközösséget azonositottam, melyek közül egyet vizsgálok jelen munkámban.

Ez a cikk a Fekete-Körös középsö és alsó vízgyüjtőinek rétjein található, a Phragmitetalia Koch 1926 rendbe, Phragmition communis Koch 196 alrendbe, és Phragmitetea australis R. Tüxen et Preising 1942 osztályba tartozó Typhetum latifoliae Lang 1973 higrofil közösséget vizsgálja cönotaxonómiai szempontból.

Kulcsszavak: ökológiai tényezök, florisztikai elemek, életformák, fitocönológiai tanulmány, növényközösségek

\section{INTRODUCTION}

This study aims to analyze the phytocoenoses of the association Typhetum latifoliae Lang 1973 from the point of view of the floristic composition and by analyzing the spectrum of the floristic elements, the life forms spectrum, the karyotype spectrum and the ecological factors.

The territory chosen for research, the meadowlands from the middle and inferior basin of Crisul Negru river, had not been studied thoroughly by those who had floristic and phytocoenological concerns and were not made many scientific communications and publications about this area. Dissipated data on small segments were found in the author's paperwork's Borza (1929), Pop (1968) and Prodan (1956). In their work the cited authors were related to a larger area without having done thorough studies.

The complex study of flora and vegetation is absolutely necessary especially in regions with less or no researches.

This association is common in our country and has been described by many author's, including: in Oltenia (Roman, 1974), in Moldova (Mititelu et Barabaş, 1971; Chifu et al., 2006), in Transilvania (Kovács, 1969; Pop et al., 2002), in Muntenia (Ştefan, 1980), in Maramureş (Resmeriţă et Raţiu, 1974).

The association is also widespread in the Pannonian region (Borhidi, 2003).
Type of habitat: Danubian communities with Typha angustifolia and Typha latifolia, code R5305 (Doniţă et al., 2005).

\section{MATERIAL AND METHODS}

The basin of Crişul Negru river (Figure 1), about $3820 \mathrm{~km}^{2}$, is located between geographic coordinates $46^{\circ} 22^{\prime}$ and $47^{\circ} 00^{\prime}$ north latitude, respectively $21^{\circ} 24^{\prime}$ and $22^{\circ} 45^{\prime}$ eastern longitude (in WGS 84 coordinate).

The basin of Crişul Negru river is surrounded by the Crişul Repede basin in the north and in the south by the basin of Crisul Alb river. Western limit of the basin is formed by the state border with the Republic of Hungary and the east limit with the basins of Somes and Aries rivers. Except for the area occupied by the basin of Teuz valley, the basin of Crişul Negru river extends entirely across the Bihor county, representing $60 \%$ of its territory.

From the climate perspective, the basin of Crişul Negru river, as part of Crişurilor basin, falls within the Pannonian climate with wide variety of overtones, depending on the complexity and fragmentation of the landscape. The arrangement of the relief steps is in ascending order from west to east, making the whole basin to be under the influence of oceanic air masses from the west and those subtropical wet, especially in winter, on slopes facing southwest (Cristea, 2004). 
Figure 1: The basin of Crişul Negru river (North-Western Romania)

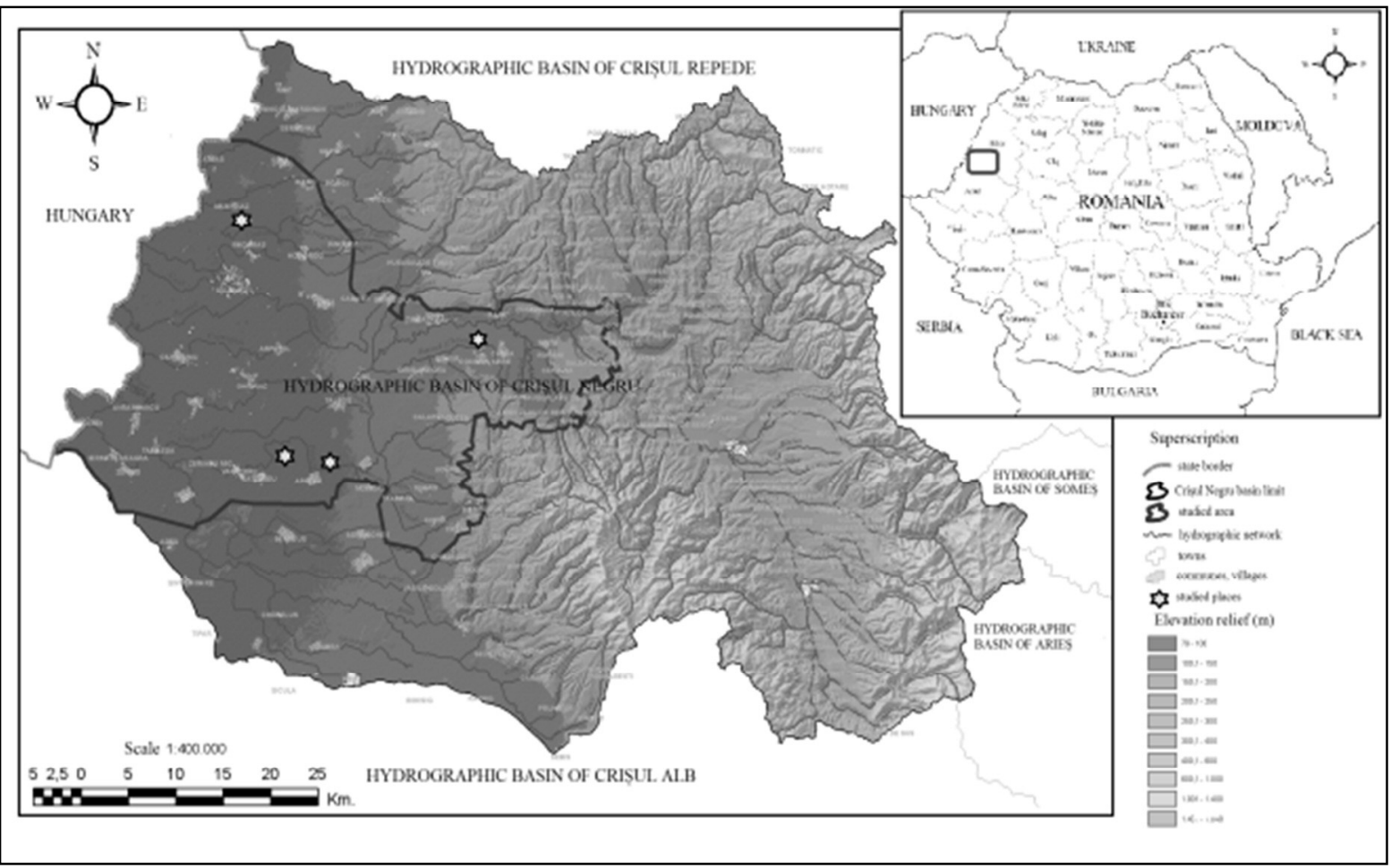

The soils of the Crişul Negru Plain are characterized by diversity (Barbu, 1987), their genesis being in close connection with the evolution of the Plain of Tisa. The region from the Plain of Crişul Negru is tessellated; the inter-region soils dominate (alluvial, swamp soil, gleic soil and pseudogley, salty soils).

A part of the middle and inferior basin of the Crişul Negru River, being covered with primary herbaceous vegetation, has been broken up and used for agriculture. The meadows which hasn't been broken up, used by humans as pastures and meadows; as a result of canalizations and drainages these meadows suffered a saline progradation, and secondary halophile vegetation appeared, vegetation which is widely spread in this area.

On taking into consideration several papers in the specialty literature (Sanda et al., 1998, 2008), the Typhetum latifoliae association Lang 1973 was classified in the following coenosystem:

Class: Phragmitetea australis R. Tüxen et Preising 1942 ,

Order: Phragmitetalia Koch 1926,

Alliance: Phragmition communis Koch 1926.

For the study of Typhetum latifoliae association from the middle and inferior basin of Crişul Negru river, I used the phytosociological research method of the European Central School, based on the principles and methods elaborated by Braun-Blanquet (1964) and adapted by Borza and Boşcaiu (1965) to the particularities of the vegetation carpet from our country.

After the field research the list of species is drawn up grouped by classes, order, families and ranges alphabetically, specifying the place and habitat where they vegetate, the locality and an ecological summary (bioforms, geo-elements, ecological clues and karyotype). The taxa identified in the field have been recognized by specialty catalogues "Flora României"/Romania's Flora (Ciocârlan, 1952-1976) and "Flora ilustrată a României"/Romania's Illustrated Flora (Ciocârlan, 2000).

The association's synthetic table was structured after the methodology proposed by Braun-Blanquet (1964) and developed by Ellenberg (1974); therefore, in the column header of the table for the association analyzed the following have been entered: the serial number of land surveys, altitude (m.s.m.), area $\left(\mathrm{m}^{2}\right)$, coverage $(\%)$.

Participation of each species to the association table was made with the help of the index of abundancedominance after the evaluation system of BraunBlanquet and Pavillard (1928). To the end of the table was registered and calculated the constancy $(\mathrm{K})$, the phytocenotical index whose class is between $\mathrm{I}-\mathrm{V}$ and expresses the coenetic fidelity degree of each species to the ambiance of the association's phytocoenoses.

To realize this study, there were performed a total of ten local incursions, and about eighty phytocoenological surveys on natural grasslands. The sample (survey) surfaces, homogenous in floristic and physiognomic terms, were chosen from the studied natural grasslands. Their size varies between $20-60 \mathrm{~m}^{2}$.

The analyzed phytocoenoses were identified on Frunzişului Valley near Apateu and Satu Nou villages (Arad county, Romania) on 16. 07. 2011 (surveys no. 1, 2); on Rătășelului Valley (Bihor county, Romania) on 29. 07. 2011 (survey no. 3); on water retaining dam near Mărţihaz village (Bihor county) on 25. 08. 2011 (survey no. 4).

Beside the Typhetum latifoliae association Lang 1973, in the studied territory I have identified other associations, such as: Lemno-Salvinietum natantis 
Miyawaki et J. Tüxen 1960, Pulicario-Menthetum pulegii Slanvnić 1951, Scirpo-Phragmitetum Koch 1926, Agrostio-Beckmannietum Rapaics 1916, Soó 1933, Glycerietum fluitantis Eggler 1933 etc.

\section{RESULTS AND DISCUSSION}

The floristic and phytocoenological characterization of Typhetum latifoliae association Lang 1973 reveals that the composition includes seventeen varied species (Table 1).

Typha latifolia builds good contoured phytocoenoses, that develops in the form of clusters at the edge of lakes, ponds, water retaining dams and swampy areas where water stagnates almost all vegetable season, not exceeding the depth of $40-50 \mathrm{~cm}$.
The phytocoenoses is dominated by Typha latifolia, that realizes a covering of vegetation of $75 \%$, with a high constancy (V), and is accompanied by the characteristic species of the Phragmition communis alliance, Phragmitetalia order, Phragmitetea australis class, namely: Lycopus europaeus, Alisma plantagoaquatica, also with a high constancy (IV), Glyceria fluitans, Eleocharis palustris, Lythrum salicaria, Sparganium erectum ssp. neglectum with a constancy of III in the frame of association.

It can be noticed the presence of transgressive mezohydrophilic and hydrophilic species from MolinioArrhenatheretea class, from which I mention: Galium palustre, Juncus effusus, Agrostis stolonifera, Juncus articulatus and Mentha longifolia.

Table 1.

Typhetum latifoliae Lang 1973

\begin{tabular}{|c|c|c|c|c|c|c|c|c|c|c|c|c|}
\hline L.f. & F.e. & $\mathrm{W}$ & $\mathrm{T}$ & S.r. & $2 n$ & $\begin{array}{l}\text { No. Land Surveys } \\
\text { Altitude (m.s.m.) } \\
\text { Area }\left(\mathrm{m}^{2}\right) \\
\text { Coverage of grass layer }(\%)\end{array}$ & $\begin{array}{c}1 \\
184 \\
60 \\
80\end{array}$ & $\begin{array}{c}2 \\
184 \\
20 \\
90\end{array}$ & $\begin{array}{c}3 \\
155 \\
40 \\
85\end{array}$ & $\begin{array}{c}4 \\
95 \\
25 \\
90\end{array}$ & $\mathrm{~K}$ & $\mathrm{ADm}$ \\
\hline $\mathrm{Hh}$ & Cosm & 6 & 3.5 & 0 & $\mathrm{D}$ & As. Typha latifolia & 4 & 5 & 4 & 5 & $\mathrm{~V}$ & 75 \\
\hline & & & Phra & ition & mmun & s, Phragmitetalia, Phragmiter & & & & & & \\
\hline $\mathrm{Hh}$ & Eua & 5 & 3 & 0 & $\mathrm{D}$ & Lycopus europaeus & 1 & + & + & . & IV & 1.5 \\
\hline $\mathrm{Hh}$ & Cosm & 6 & 0 & 0 & $\mathrm{D}$ & Alisma plantago-aquatica & + & . & + & + & IV & 0.3 \\
\hline $\mathrm{Hh}$ & Cosm & 5 & 3 & 0 & $\mathrm{P}$ & Glyceria fluitans & + & . & + & . & III & 0.2 \\
\hline G-Hh & Cosm & 5 & 0 & 4 & D-P & Eleocharis palustris & + & . & + & . & III & 0.2 \\
\hline $\mathrm{H}-\mathrm{Hh}$ & Cosm & 4 & 3 & 0 & $\mathrm{P}$ & Lythrum salicaria & + & + & . & . & III & 0.2 \\
\hline $\mathrm{Hh}$ & Eua & 6 & 4 & 0 & & $\begin{array}{l}\text { S. erectum ssp. neglectum } \\
\text { linio-Arrhenatheretea }\end{array}$ & . & + & . & + & III & 0.2 \\
\hline $\mathrm{H}$ & $\mathrm{Cp}$ & 5 & 3 & 0 & D-P & Galium palustre & + & . & + & . & III & 0.2 \\
\hline $\mathrm{H}$ & Cosm & 4.5 & 3 & 3 & $\mathrm{P}$ & Juncus effusus & + & . & + & . & III & 0.2 \\
\hline G & $\mathrm{E}$ & 0 & 3 & 0 & $\mathrm{P}$ & Carex hirta & . & + & . & + & III & 0.2 \\
\hline $\mathrm{H}$ & $\mathrm{Cp}$ & 4 & 0 & 0 & $\mathrm{P}$ & Agrostis stolonifera & + & . & + & . & III & 0.2 \\
\hline $\mathrm{H}$ & $\mathrm{Cp}$ & 5 & 2 & 0 & $\mathrm{P}$ & Juncus articulatus & + & . & + & . & III & 0.2 \\
\hline $\mathrm{H}$ & Eua & 4.5 & 3 & 0 & $\mathrm{P}$ & $\begin{array}{l}\text { Mentha longifolia } \\
\text { Variae Syntaxa }\end{array}$ & + & . & . & + & III & 0.2 \\
\hline Th & Eua & 4.5 & 3 & 0 & $\mathrm{P}$ & Bidens tripartita & . & + & + & . & III & 0.2 \\
\hline $\mathrm{Hh}$ & Cosm & 6 & 2.5 & 4 & $\mathrm{P}$ & Potamogeton natans & 1 & . & 2 & . & III & 5.6 \\
\hline $\mathrm{Ch}$ & Eua & 4.5 & 3 & 4 & $\mathrm{D}$ & Solanum dulcamara & + & . & + & . & III & 0.2 \\
\hline $\mathrm{Ch}$ & $\mathrm{E}$ & 4 & 3 & 0 & $\mathrm{P}$ & Lysimachia nummularia & + & . & . & + & III & 0.2 \\
\hline
\end{tabular}

Note: Phytocoenological table of Typhetum latifoliae association Lang 1973, where: L.f. - life forms; F.e. - floristic elements; W - soil wet; T - temperature; S.r. - chemical reaction of the soil; 2n - karyotype; K - constancy; ADm - abundance-dominance; Hh - helohydatophyte; H - hemicrypthopyte; G - geophytes; Th - euterophytes; Ch - chamaephytes; Cosm - Cosmopolitan; Cp - Circumpolar; Eua - Eurasian; E European; D - diploidy; P - polyploidy; D-P - diplo-polyploidy.

The analysis of the Typhetum latifoliae association on the aspect of the main ecological factors (Figure 2) emphasize the dominant mezo-hydrophilic character of the species $\left(\mathrm{W}_{4-4.5}=41.16 \%\right)$, followed by the hydrophilic and hydrophytic character $\left(\mathrm{W}_{5}=29.41 \%\right.$, $\mathrm{W}_{6}=23.52 \%$ ). Depending to the temperature, the association has a micro-mesotherm character $\left(\mathrm{T}_{3-3,5}=\right.$ $64.7 \%$ ), followed by thermic amphitolerant species $\left(\mathrm{T}_{0}=17.64 \%\right)$, and considering the chemical reaction of the soil, it manifests a chemical amphitolerant character (S.r. $=76.47 \%$ ) along with a slightly acidneutrophile character (S.r. $4=17.64 \%$ ).
Figure 2: Diagram of ecological factors for the association Typhetum latifoliae Lang 1973

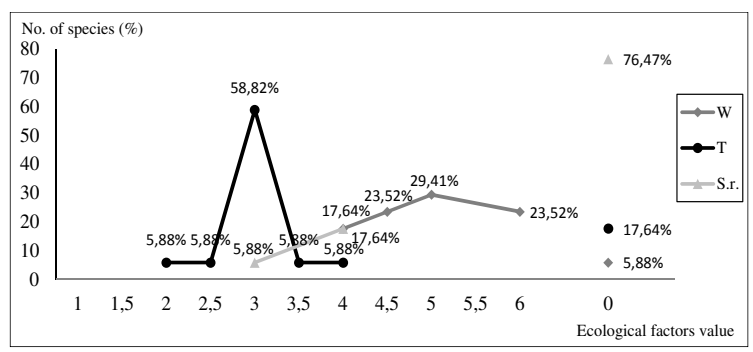

Note: W - soil wet; T - temperature; S.r. - the chemical reaction of the soil 
The life forms spectrum of the association (Figure 3) points out the preponderance of helohydatophytes $(\mathrm{Hh}=35.29 \%)$ along with hemicryptophytes $(\mathrm{Hh}=$ $35.29 \%$ ), followed by geophytes and chamaephytes $(11.76 \%)$.

Figure 3: The life forms spectrum of association Typhetum latifoliae Lang 1973

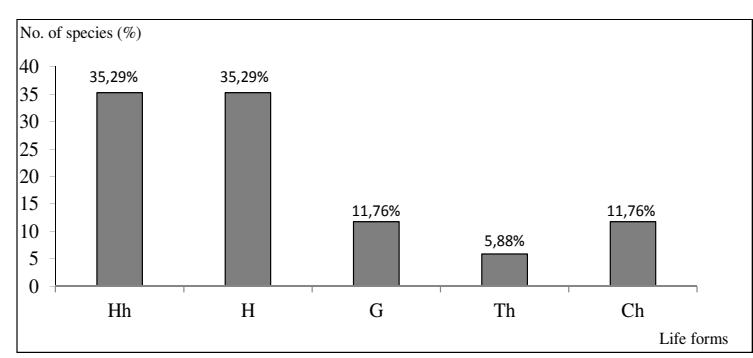

Note: Hh - helohydatophyte; H - hemicrypthopyte; G - geophytes; Th - euterophytes; $\mathrm{Ch}$ - chamaephytes

The spectrum of the floristic elements (Figure 4) is dominated by the Cosmopolite species (Cosm= $41.17 \%$ ), followed by Eurasian species (Eua=29.41\%) and Circumpolar species $(\mathrm{Cp}=17.64 \%)$.

Figure 4: The floristic elements spectrum of the association Typhetum latifoliae Lang 1973

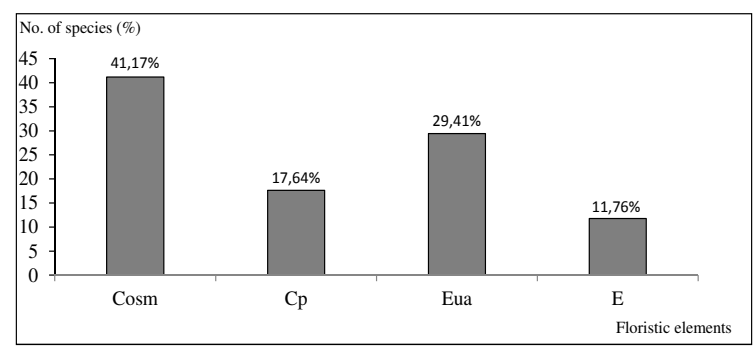

Note: Note: Cosm - Cosmopolitan; Cp - Circumpolar; Eua Eurasian; E - European
The polyploid species are dominant in the karyotype spectrum (Figure 5) with a percentage of $58.82 \%$, followed by the diploid species with a percentage of $29.41 \%$ and the diplo-polyploid species with $11.76 \%$.

Figure 5: The karyotype spectrum of association Typhetum latifoliae Lang 1973

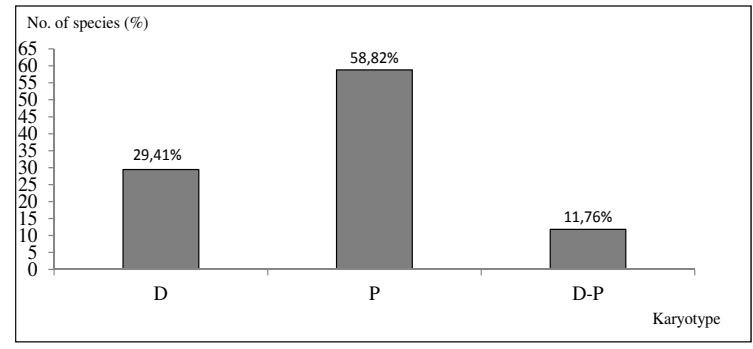

Note: D - diploidy; P - polyploidy; D-P - diplo-polyploidy

\section{CONCLUSIONS}

The present work report for the first time the $T y$ phetum latifoliae Lang 1973 association in the studied area.

Analysis of ecological indices for the associations found on the grasslands of the middle and inferior basin of Crisul Negru river highlight in terms of the soil wet the highest weight among mezo-hydrophilic species, in terms of temperature the micro-mesotherm species and in terms of the chemical reaction of the soil the predominant species are the chemical amphitolerant.

The floristic elements spectrum shows that the cosmopolitan species are in a larger number, which means that the floristic composition of the association has a wide geographical spread.

The significance and the practical value of this study emerges from the fact that research results can serve as a guide for local authorities or as a scientific material for researches in biology, ecology, environmental protection, regional geography.

\section{REFERENCES}

Barbu, N. (1987): Geografia solurilor României. Centrul de multiplicare al Universităţii "Al. I. Cuza". Iaşi.

Borhidi A. (2003): Magyarország növénytársulásai. Akadémiai Kiadó. Budapest.

Borza, Al. (1929): Vegetaţia şi flora Ardealului. Schiţă geobotanică Atelierele grafice "Cultura Naţională". Bucureşti.

Borza, Al.-Boşcaiu, N. (1965): Introducere în studiul covorului vegetal. Edit. Acad. R. P. R. Bucureşti.

Braun-Blanquet, J. (1964): Pflanzensoziologie. $3^{\text {rd }}$ ed. Springer Verlag. Wien-New York.

Braun-Blanquet, J.-Pavillard, J. (1928): Vocabulaire de sociologie végétale. $3^{\text {rd }}$ ed. Imprimerie Roumegous \& Dehan. Montpellier.

Chifu, T.-Mânzu, C.-Zamfirescu, O. (2006): Flora şi vegetaţia Moldovei (România). vol. I-II. Edit. Univ. Al. I. Cuza Iaşi.

Ciocârlan, V. (2000): Flora ilustrată a României. Pteridophyta et Spermatophyta. Editura Ceres. București.

Cristea, M. (2004): Riscurile climatice din bazinul hidrografic al Crișurilor. Edit. Abaddaba. Oradea.
Cristea, V.-Gafta, D.-Pedrotti, F. (2004): Fitosociologie. Editura Presa Universitară Clujeană. Cluj-Napoca.

Doniţă, N.-Popescu, A.-Paucă-Comănescu, M.-Mihăilescu, S.Biriș, I. A. (2005): Habitatele din România. Editura Tehnică Silvică. Bucureşti.

Ellenberg, H. (1974): Zeigerwerte der Gefässpflanzen Mitteleuropas - Scripta Geobotanica. Göttingen. 9: 1-97.

Kovács, A. (1969): Vegetaţia palustră şi higrofilă din împrejurimile oraşului Târgu Secuiesc (jud. Covasna). Com. Bot. Soc. Şti. Biol. Rom. Bucureşti. 8: 27-40.

Mititelu, D.-Barabaş, N. (1971): Asociaţii noi în vegetaţia Moldovei. Comunic. ştiinţifice Inst. Pedagogic Iaşi. 365-368.

Pop, I. (1968): Flora şi vegetaţia Câmpiei Crişurilor. Interfluviul Crişul Negru-Crişul Repede. Editura Academiei R. S. R. Bucureşti.

Pop, I.-Cristea, V.-Hodişan, I. (2002): Vegetaţia judeţului Cluj. Studiu fitocenologic, ecologic, bioeconomic şi ecoprotectiv. Contrib. Bot. (1999-2000). Cluj-Napoca. 35. 2: 5-254. 
Prodan, I. (1956): Aspecte din vegetaţia zonei de vest a Republicii Populare Române. Bul. Şt. Acad. R. P. R. Secţia biol. şi ştiinţe agric. 8: 1 .

Resmeriţă, I.-Raţiu, O. (1974): Vegetaţia higro- şi hidrofilă din Maramureş. Contrib. Bot. Cluj-Napoca. 115-129.

Roman, N. (1974): Flora şi vegetaţia din sudul Podişului Mehedinţi. Editura Academiei. Bucureşti.
Sanda, V.-Popescu, A.-Barabaş, N. (1998): Cenotaxonomia și caracterizarea grupărilor vegetale din România. Studii şi comunicări - complexul muzeal de ştiinţele naturii Bacău. Borcea. Bacău.

Sanda, V.-Öllerer, K.-Burescu, P. (2008): Fitocenozele din România. Sintaxonomie, structură, dinamică şi evoluţie. Editura ARS Docendi. Universitatea din Bucureşti.

Ştefan, N. (1980): Cercetarea florei şi vegetaţiei din bazinul superior la râului Râmnicu Sărat. Rezumatul tezei de doctorat. Iași. 
